\title{
11 The Belt and Road Initiative in South Asia
}

\author{
Regional Impact and the Evolution of Perceptions and \\ Policy Responses
}

\author{
Richard Ghiasy
}

\begin{abstract}
Chapter 11 examines how the BRI has impacted South Asia. It investigates how academic perceptions and policies have evolved in India and Pakistan in response to the BRI since 2013. These two states provide a unique agency, defined as the ability to influence or resist influence, in the BRI context. The region's dominant power, India, is a staunch critic that refuses to sit at the BRI table. The region's other power, Pakistan, hosts the BRI's flagship project, the China-Pakistan Economic Corridor (CPEC), and is the single largest recipient of BRI investment. Through interviews with leading Indian and Pakistani academics, the chapter shows how they make sense of China in the region, providing understanding of the BRI's interplay with South Asia's various geopolitical fissures.
\end{abstract}

Keywords: Belt and Road Initiative, South Asia, China, India, Pakistan, agency

This chapter explores how the Belt and Road Initiative (BRI) has impacted connectivity and integration in South Asia. Following this, it investigates how academic perceptions and policies have evolved in the region in response to the BRI since its inception in 2013. ${ }^{1}$ Most countries in the

1 Academic perceptions tend to trickle down into policy advice and making. However, this chapter does not describe in which instances exactly this may have been the case.

Schneider, Florian (ed.), Global Perspectives on China's Belt and Road Initiative: Asserting Agency through Regional Connectivity. Amsterdam, Amsterdam University Press 2021 DOI: 10.5117/9789463727853_CH11 
region are discussed but the emphasis is on India and Pakistan. ${ }^{2}$ These two states provide a unique agency, in this chapter the ability to influence or resist influence, disparity in the BRI context. The region's dominant power, India, is a staunch critic that refuses to sit at the figurative BRI table. India is exemplary of the degree to which a non-partaking actor can counter, or supplement, the BRI in its region. The region's other power, Pakistan, hosts the BRI's flagship project, the China-Pakistan Economic Corridor (CPEC), and is the single largest recipient of BRI investment. Pakistan provides insight into how a deep-seated partaker's perceptions and policies on the BRI have evolved. Moreover, this chapter grants an understanding of the BRI's interplay with South Asia's various geopolitical fissures. To permit tailored data collection, the author conducted a series of interviews with leading Indian and Pakistani academics on a non-attributive basis. ${ }^{3}$ Reference to these interviews is made where due. The next section will explore three critical regional realities significant to the initiative.

\section{South Asia's Three Critical Realities}

Strategically South Asia, together with Southeast Asia, is the most important expanse to the BRI. For China, both regions are terrestrial gateways to the Indian Ocean. South Asia is also economically the world's fastest-growing region, growing at an average of $7 \%$ since 2014 (Song 2019). To understand the impact of the BRI on South Asia, and corresponding perceptions and policy responses, it is essential to first contemplate three critical regional realities significant to the initiative: 1) South Asia's distinct geography; 2) the region's deep-rooted geopolitical landscape; 3 ) the underpinnings of Indian-Chinese political ties. These realities are partially interrelated.

2 Myanmar is analysed by Matt Ferchen in his chapter on Southeast Asia (Chapter 10) in this volume. Neither is Bhutan part of the analysis, though there is a sporadic reference. Bhutan's foreign and defence policies are closely coordinated by India, as evidenced by the 2017 Doklam standoff between India and China. Bhutan has no diplomatic ties with China and is not part of the BRI. China tried to woo Bhutan to join the BRI in July 2018, to no avail.

3 Semi-structured non-attributive interviews with leading Indian academics from ten different institutes were conducted in New Delhi in September 2019. A series of non-attributive semi-structured interviews with leading Pakistani academics from five different institutes were conducted through Skype in September-October 2019. 


\section{Distinct Geography}

South Asia's distinct geography is a 'static reality'. Certainly, border conflicts characterize the region, but India's setting in the region is unlike any other in Asia. Like a monolith, India sits right at the centre of the region across four dimensions: geographic, political, economic, and historical/cultural. India borders four of the five regional, continental states: Bangladesh, landlocked Bhutan, landlocked Nepal, and Pakistan (see figure 11.1). The exception is Afghanistan. Meanwhile, the island states of the Maldives and Sri Lanka are situated closer to India than any other continental South Asian state.

Remarkably, none of the South Asian states border a regional state other than India. The region's states are therefore highly dependent on India for intra-regional (land) connectivity. Pakistan also borders Afghanistan, but landlocked Afghanistan is considered as the crossroads of South and Central Asia. Meanwhile, Bangladesh borders Myanmar, but Myanmar is an Association of Southeast Asian Nations (ASEAN) member and is more often classified as part of that region. ${ }^{4}$ The geographic centrality of India, the regional hegemon, limits smaller states' agency. It is something that makes South Asia stand out when compared to Southeast, Central and West Asia (the Middle East). Kaplan (2013: 228-254) and Marshall (2019: 189-216) elaborate on this in more detail. Besides India, the region's other common neighbour and geographic reality is China, the only country that is contiguous to every subregion of Asia. ${ }^{5}$ Except for Bangladesh, all of the continental states in South Asia border China. Therefore, both literally and figuratively, South Asian states sit between an emerging India, a more swiftly re-emerging China, and these two powers' diverging visions for connectivity.

\section{A Deep-Rooted Geopolitical Landscape}

The region's other reality, somewhat more fluid than its distinct geography, is that South Asia is rife with geopolitical tensions that intermingle with the BRI. These tensions and divisions have extended and continue to extend extra-regionally. China still sides with Pakistan, while the US has shifted away from Pakistan and towards India to counter China in the Indo-Pacific.

4 Afghanistan was considered part of the Greater Middle East (as is Pakistan in that classification) in US policies at the time of the George W. Bush administration. Regarding Myanmar, despite being an ASEAN member, major authorities (such as the World Bank in its Data series) exclude it from South Asia. Neither is the country geographically part of the Indian subcontinent. 5 If indeed Afghanistan is considered a part of the Greater Middle East, see also the previous footnote. 
Figure 11.1 India's unique geographic centrality in South Asia

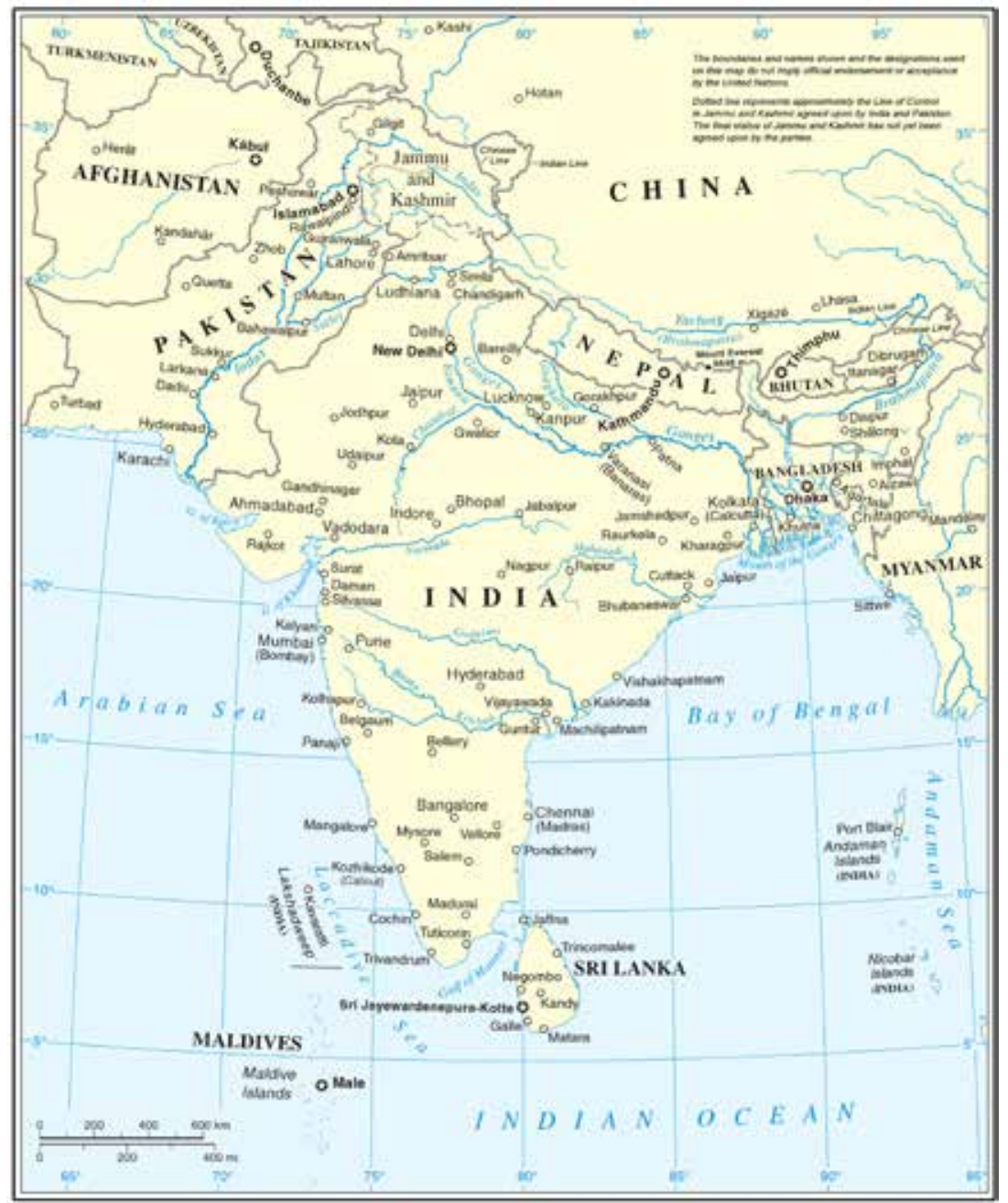

Source: Image in the public domain, via the United Nations ${ }^{6}$

The deep geopolitical acrimony between the nuclear-armed actors India and Pakistan continues to hold regional integration hostage. ${ }^{7}$ Low-intensity interstate (border) conflict frequently erupts between India and Pakistan,

6 Note that this map does not depict disputed areas comprehensively or in detail.

7 For a detailed record of the partition of India and the acrimony that has since characterized India-Pakistan relations, see Parts 1 and 2 of Ramachandra Guha's monumental work India after Gandhi (2017). 
as it did again in and over Kashmir in 2019. Pakistan also has very testing ties with its other neighbour, Afghanistan. ${ }^{8}$ The geographic centrality of India and these testing ties with Afghanistan result in Pakistan having no strategic depth to speak of. Moreover, ethnic and sectarian tensions are scattered through South Asia. As a result, this is where some of the world's most severe traditional and non-traditional security challenges congregate. These security challenges are ones with which the BRI needs to deal.

However, the largely impoverished region is also strikingly disconnected. This is partly because, between the 1950s and the start of the 1990s, India deliberately pursued disconnection policies to insulate itself from foreign influences. The trip to Sri Lanka in 2015 by the current Prime Minister of India, Narendra Modi, for example, was the first such official bilateral visit by an Indian Prime Minister since 1987 (Xavier 2020: 12). ${ }^{9}$ Naturally, smaller states' regional connectivity, which was overly dependent on Indian geographic centrality and policy, was affected by these disconnection policies. As such, intra-regional trade still remains relatively negligible. Xavier demonstrates this well by pointing out that India's land-based trade with neighbour Myanmar is about the same as India's total trade with distant and tiny Nicaragua (2020: 7 ).

Since it began implementing economic reforms in 1991, India has been pursuing greater connectivity with and beyond the region - albeit sluggishly. For comparison, intra-regional trade in East Asia is around $50 \%$ of the region's total trade, while in South Asia that figure is only $5 \%$ (World Bank 2018). Still, this pursuit has put India at the centre of regional connectivity initiatives and the pace has picked up under the current, more strategic, Modi administration. India, like any other state, requires a buffer of stability and prosperity in the region for its national security. The BRI's growing footprint is affecting Indian national security on the Indian subcontinent and in the Indian Ocean region.

\section{Underpinnings of Indian-Chinese Political Ties}

Third, and tied to the first two critical realities, perceptions of the BRI have to be understood in the broader context of India-China relations. India and China have had a complicated political relationship since the second half of the twentieth century. During India's partition, China sided with Pakistan.

8 Barfield 2010 grants a well-researched historic background to these testing ties.

9 Though it should be noted that there have been several bilateral state visits to other South Asian states during that time. 
Strategic distrust has persisted in Indian military, policy, and academic communities since a brief war with China in 1962. The war, which India lost, was over a border dispute between the two states. In addition, border disputes with China linger, and then there is China's all-weather friendship with India's arch-rival Pakistan. In 2010, Grant correctly concluded that 'Indians are much more nervous about the rise of China, New Delhi's foreign policy and defence establishments, in particular,' than the other way around (Grant 2010: 1). The BRI's expansion in South Asia, and a perceived encirclement by China, have amplified this Indian distrust of and nervousness about China (Sibal 2014). This plays a prominent role in the region's geopolitical landscape. For China on the other hand, India forms a massive geographic wedge in its terrestrial access to the Indian Ocean.

Irrespective, China is India's second-largest trading partner after the US. However, the balance is vastly tilted in China's favour, amounting to US\$87.07 billion on average in 2018-2019 (Times of India 2020). The two countries have rather similar stances on global issues such as climate change and they strive for a multi-polar global order. They frequently meet at fora such as the Shanghai Cooperation Organisation (SCO) and the Brazil, Russia, India, China, and South Africa (BRICS) summit. India is also the second-largest stakeholder in the China-initiated Asian Infrastructure Investment Bank (AIIB) and the largest beneficiary of its concessional loans (Sachdeva 2018: 289). Moreover, Chinese President Xi Jinping and Narendra Modi have already met eighteen times since Modi became the Indian Prime Minister in 2014. ${ }^{10}$ These examples demonstrate that the relationship is also characterized by high-level political consultation and economic cooperation, just not under the BRI banner. This is a paradox partially sustained by a hunger for foreign investment and lax Indian regulation on Chinese investment. It should be noted that at the moment of writing Indian policies on Chinese investment in sectors that are deemed vital to national security, particularly tech, are becoming more stringent.

The establishment of these three regional realities present in South Asia enables a more nuanced exploration of BRI impact on South Asia.

\section{BRI Regional Impact}

This section provides an analysis of how, since its inception, the BRI has impacted connectivity and integration in South Asia. First, it briefly examines

10 This number includes visits to each other's countries and meetings on the sidelines of international summits. 
Chinese strategic interests in South Asia. Following this, it explores the BRI's impact on connectivity and integration.

\section{Chinese Interests}

Why is China so interested in South Asia at large and Pakistan, in particular? China's push in South Asia, carried out through the BRI, pursues greater autonomy. It seeks to diversify and secure China's supply chains in the Indian Ocean, including energy imports from Africa and the Middle East. From a BRI perspective, South Asia's geography is of considerable strategic value. The two components of the BRI, the land-based 'Silk Road Economic Belt' (hereafter the 'Belt') and the maritime-based '21st-Century Maritime Silk Road' (hereafter the 'Road'), connect in South Asia. It is important to remember that the Belt and Road should not be seen as two distinct components, but as a mutually synergizing whole that helps China achieve strategic goals through conflict-evasive means (Ghiasy 2018). Also, the size and potential of investment and consumer markets in South Asia, in contrast to Central and Northeast Asia for example, is tremendous.

Furthermore, by means of the BRI, China's west, specifically the landlocked Xinjiang Uygur Autonomous Region, can connect with the Indian Ocean via Pakistan. Meanwhile, the equally landlocked Yunnan Province in China's south-west, and Tibet Autonomous Region in the south, can connect with that same ocean through Myanmar. In turn, Pakistan is the only country in South Asia through which China can bypass the US Navy-patrolled straits in and around Malacca. That grants China supply lines to and from the Indian Ocean directly overland without needing to trespass a third country. Indeed, China's strategic interests in the region are undeniable. China's interest in the region is shown by the way it has made investments in ports across South Asia, for instance in Gwadar (Pakistan), Hambantota (Sri Lanka), and Chittagong (Bangladesh). From an Indian defence perspective such investments in its sphere of influence, and the prospect of the dual-use of these ports, is deeply worrisome (interview, Delhi, September 2019). However, China is not the only actor to become more active in the security affairs of the Indian Ocean region: this region is gradually becoming a multipolar security space (Brewster 2016).

\section{A Connectivity Catalyst in a Disconnected Region}

BRI regional impact on South Asia can be viewed along two strands: cooperation on connectivity, and competition for connectivity. The BRI has provided 
an impetus to connect ${ }^{11}$ in a fragmented and disconnected region that is home to 1.8 billion citizens or $24 \%$ of humanity (World Bank Data 2020). ${ }^{12}$ In the region, the concept of connectivity has now taken on a new importance, and a spirit of development coordination has gradually emerged (Ghiasy et al. 2018). On balance, the region, bar India, has benefitted from better national and extra-national connectivity owing to the BRI (Samaranayake 2019). Examples of projects that have directly or indirectly contributed to this include rails and roads in Pakistan, ports such as Chittagong and an industrial zone and international exhibition centre in Bangladesh, cities such as Colombo Port City in Sri Lanka, airport upgrades and a prominent bridge in the Maldives, and hydropower projects in Nepal. However, it should be noted that infrastructure on its own does not lead to better connectivity per se. Equally important are the design and enforcement of policies that stimulate closer regional integration, or so-called 'soft connectivity'. This, however, is not in China's hands, but a matter of local leadership and enterprise.

To India, the BRI has acted as a trigger for a blossoming of regional and extra-regional connectivity initiatives. Since the launch of the BRI, India has initiated five major connectivity initiatives (which will be elaborated on in the specific subsection on India). Indirectly, the BRI has also pushed Japan, the US, and the EU, through its Connectivity Strategy, to allocate more infrastructure investment to South Asia and the Indian Ocean region. Although none of these alternative connectivity initiatives carry the BRI's financial and diplomatic clout, the BRI has acted as a game-changing pushand-pull factor. This role can be labelled a positive side effect.

At the same time, however, the BRI has also intensified historic geopolitical competition over influence and security between China and Pakistan on the one hand, and India on the other. Smaller states in the region are caught in the middle. They now need to attempt to balance Chinese and Indian interests. India is a closer geographic reality and power than China. However, substantial factions in many of these states (with the exception of Afghanistan and Bhutan) have been or are still wary of India's dominance and so welcome China's re-emergence in the region (Pakistani interviewees based in Islamabad, September 2019, via Skype). With China more active in the region, these states can better

11 Moreover, BRI gains should not merely be judged in their hard infrastructure manifestation. Benefits are also derived from adjustments to institutional, legal, and market frameworks that increase overall trade (Fengler \& Vallely 2019).

12 Statistics exclude Myanmar. 
balance India's dominant role, attract investment, and can gain bargaining power vis-à-vis India. In this regard, smaller states have gained agency in South Asia.

An example of how this increased competition in the region between China and India might benefit smaller states was seen in 2016. The People's Republic of China (PRC) central government committed a US\$38 billion economic package to Bangladesh. Then, barely half a year later, the Indian government sought to counter Chinese efforts by providing a US $\$ 5$ billion line of credit and other economic assistance to Bangladesh. This was the biggest single line of credit that India had ever extended to any country (Chakma 2019: 228). On another occasion, in 2018, India similarly sought to counter China by offering US\$1.4 billion in financial aid to the Maldives for infrastructure development (Ganapathy 2018).

\section{Integration of the Region or Integration with China?}

Even though Indian observers acknowledge that China has a legitimate interest in the Indian Ocean to protect its supply lines, many of these observers believe that the Road is a proxy for China's strategic ambitions and part of its 'String of Pearls' strategy ${ }^{13}$ (Singh 2019: 206). According to Singh (2019: 208) and Borah (2018), many Indian analysts believe that as part of this strategy China's People's Liberation Army Navy (PLAN) wants to dominate trans-continental littorals. These analysts see this ambition from China as something that significantly impacts India's security interests. According to one interviewee (Delhi, September 2019), China is using micro-steps to encroach on and make advancements in South Asia's security realm: first through diplomacy, then through the economy, and then into security. Over time, in the aggregate, these micro-steps become major strides. Another Indian interviewee (Delhi, September 2019) made a similar argument: 'China is trying to organically create a need for PLAN as if it is rendered necessary by supply chain protection, or circumstances such as a humanitarian disaster. That way, they will obtain incremental control.' Whereas these statements have a speculative nature, they are indicative of prevailing views of encirclement by China and are bound to feed into Indian policy-making processes.

The (perceived) encirclement is terrestrial as well. China has been insensitive to Indian territorial integrity and one of India's core interests:

13 A geopolitical theory introduced by the US and highly popular in Indian policy and academic circles claims that China premeditates a network of commercial and military facilities and relationships from its mainland through the Indian Ocean to the Horn of Africa. 
India-claimed and Pakistan-occupied Kashmir. Part of Kashmir is known in Pakistan as Gilgit-Baltistan, ${ }^{14}$ which the China-Pakistan Economic Corridor (CPEC) crosses. One interviewee (Delhi, September 2019) asked how China would feel if India were to go against China's core interests in, for example, Hong Kong, Taiwan, or the South China Sea. The interlocutor went further and stated that the rift between India and Pakistan is being sustained and hardened by the BRI. They said that, instead of closer integration, there is now an East South Asia and a West South Asia. This schism is perhaps somewhat overstated, as there was a(n) (in) visible rift in South Asia long before the BRI surfaced. However, it is true that the BRI has bolstered Pakistan's position and further complicated the Kashmir dispute. On the other hand, there is growing awareness in Pakistan and China that the CPEC makes limited economic sense if India and Afghanistan are not part of it (two interviewees based in Islamabad, October 2019, via Skype). Currently, BRI connectivity in continental South Asia courses vertically, i.e. it runs from China to Pakistan and then down through Pakistan to the Arabian Sea. There is no CPEC horizontal integration with either of Pakistan's regional neighbours, India or Afghanistan. However, this is a conscious choice that has been made by India, while Afghanistan has an uneasy relationship with Pakistan and is embroiled in an ongoing civil war.

The next section will discuss how the three South Asian regional realities are linked with the BRI's regional impact and the evolution of the perceptions and policies of individual regional states.

\section{The Evolution of Perceptions and Policy Responses in South Asia}

In line with the evolution of BRI impact since 2013, academic perceptions of the initiative in South Asia have also evolved. Academic perceptions and policy responses can be characterized by drawing the analogy of who is seated at the figurative BRI table. The perceptions and policy responses of different states are reflected by who cooperates with China under the BRI banner and how they have acted. Proximity to the table indicates greater interest. The role of the region's three critical realities are interwoven in the argumentation.

14 Gilgit-Baltistan, despite being part of the larger occupied Jammu and Kashmir issue has always had a slightly different status, as it gained and announced independence from the British, and then surrendered to Pakistan, which merged it into the larger Jammu and Kashmir territory. 


\section{Not at the Table but Keeping a Very Close Eye - India}

As elaborated on above, the political relations between India and China are complex. A number of Indian scholars define that relationship through the 4 C's of conflict, cooperation, competition, and containment (Sachdeva 2018: 286). India's position regarding the BRI best fits in the latter two categories of competition and containment. India has been both competing with, and containing, the BRI since 2014. It does this not only because the BRI infringes on Indian regional influence, but also because it is convinced that the Communist Party of China (CPC) wants a unipolar Asia (Katoch 2019: 104). India perceives that more connectivity brought about by the BRI aids this CPC objective. This connectivity translates into greater strategic space and mobility for China in South Asia and the Indian Ocean, at the expense of India's operational space (interview, Delhi, September 2019). This is, of course, a correct observation.

Keeping this in mind, India's official policy on the BRI has been consistent. The Indian government has always been outspoken about CPEC. ${ }^{15}$ However, formally India has mostly remained silent about the BRI and has neither really accepted nor rejected the initiative. Perceptions of the BRI in India can be divided into two phases:

Phase I. In this phase, between 2014 and 2017, the debate centred on geopolitical and developmental implications. China officially invited India to join the BRI in February 2014. However, the Indian government did not express much enthusiasm due to 1) a lack of clarity on the initiative's economic objectives, 2) a lack of consultation by China with India and others on BRI specifics, and 3) hesitation among many Indian observers about its strategic implications (Singh 2014: 135). This complied with a constant in India's rich and long history of foreign policy: independence of action alongside a level of realism and idealism. ${ }^{16}$ The BRI mostly hit the realism string. However, India did make more cooperative moves in the broader context of the Indian-Chinese relationship. In 2014, India became a founding member of the AIIB and the New Development Bank (formerly the BRICS Development Bank). It then became a full member of the Shanghai Cooperation Organisation in 2017. Chhibber (2017) refers to the phase of relations between India and China that stretched from 2014 to 2017 as one of 'competitive cooperation'.

15 After the 2018 Wuhan summit official rhetoric has toned down, perhaps as a result of a plea by President Xi Jinping.

16 Pande 2018 offers a useful overview of ancient to contemporary Indian foreign policy. 
In the early years of this period, 2014 to 2015, Indian analysts saw the BRI both as an opportunity to boost regional connectivity and a threat to India's prominence in South Asia and the Indian Ocean region (see, for instance, Singh 2014:143; Mohan 2014a and 2014b; Nataraj \& Sekhani 2015). These same analysts suggested that India come up with its own connectivity initiatives to hedge the BRI. Simultaneously, they expressed the rationale for joining the BRI. Some academics, to no avail, recommended a partial engagement (e.g. Singh 2014; Nataraj \& Sekhani 2015: 71). Recommendations to join the BRI were based on the fact that it would give India an ability to shape the agenda and to tap an unfolding geoeconomic reality. Mohan (2014a and 2014b) defined India's official stance at the time as rigid and detrimental.

The Indian government was, however, receptive to the China-led Bangladesh-China-India-Myanmar Economic Corridor (BCIM), which predated the BRI by fourteen years. India saw the BCIM as having the potential to open up India's tribal, landlocked Northeast region. Some analysts, such as Uberoi (2016), questioned this official stance, which produced the dichotomy of the $\mathrm{BRI}$ versus the BCIM. Yet, when the Chinese state subsumed the BCIM into the BRI in 2015, Indian official interest tumbled. In that year, the Indian government continued its silent official stance on the BRI, though it publicly rejected CPEC. By and large, in this first phase, geopolitics dominated over developmental implications because of a fixation on CPEC (Sachdeva 2018: 286). This fixation is increasingly visible from 2017 onwards. In 2017, the Indian government visibly protested by not sending a single delegate to the first Belt and Road Forum in Beijing. Publicly, a day before the forum, a key Indian policy shift took off. The Indian government started to oppose the BRI as a whole rather than just CPEC by pointing to lack of compliance with international norms on transparency, economic sustainability, and debt sustainability (Ministry of External Affairs 2017). Even the fact that it gained membership of the Shanghai Cooperation Organisation in that same year did not change India's stance towards the BRI.

Five prominent initiatives. Delhi used the years between the introduction of the BRI and the first forum to up its agency. To foster its ambitions and geographic centrality, India launched five prominent initiatives: the Neighbourhood First policy (2014), the Act East policy (2014), Project Mausam (2014), Security and Growth for All in the Region (SAGAR) (2015), and, coinitiated with Japan, the Asia-Africa Growth Corridor (AAGC) (2017). ${ }^{17}$ These initiatives are important policy responses and merit elaboration.

17 A year later it was renamed 'Platform for Japan-India Business Cooperation in Asia-Africa Region'. 
The Neighbourhood First policy firmly prioritized connectivity with South Asia, not merely restricted to commerce. The Act East policy is a follow-up on the somewhat inert Look East policy from 1991. The Act East policy, combined with the Modi administration's Neighbourhood First policy - a major foreign policy - tactically rebalanced India's geostrategic orientation. India's foreign policy had long been oriented towards the West but had now become more neighbourhood- and Indian Ocean-centric (Katoch 2019: 23).

To support this shift in orientation, the Indian government introduced Project Mausam. Mausam aims to revive 'lost' maritime, cultural, and economic connections in the Indian Ocean region. It can be interpreted as India's answer to the Road. Interestingly, cultural ties are utilized as a key cohesive driver in Project Mausam. Strategically, particularly administratively, financially, and diplomatically, India simply cannot compete with China and its BRI. It has therefore had to come up with alternative ways to compete. One interviewee (Delhi, September 2019) reflected on the rationale behind Project Mausam and articulated that 'Chinese money and investment are not the only currency: cultural, lingual, historical, and religious similarities are currencies, too. Economic incentives are shortterm, while cultural relations are long term' (my emphasis). Following after Project Mausam, Prime Minister Modi announced SAGAR, a vision at the conceptual level for economic growth and security in the Indian Ocean. The partnership with Japan lacks Indian investment, and progress has been slower than Japan foresaw (interview, Delhi, September 2019).

Phase II. In this phase, which began in late 2017 or early 2018 and continues to the present, geopolitics has remained a central element. In addition, the political economy, sustainability, and practical mishaps of the BRI have increasingly come to the fore. How can this be explained? In 2018, Chinese trade in the region was five times more than India's trade with its neighbours (Xavier 2020: 10). Suspicions of the BRI on the part of the Indian government and Indian analysts continued to grow in 2018-2019. The reasons for these suspicions became more fine-grained than mere geopolitics, they were 1) geoeconomic, 2) geostrategic, and 3) of a security nature.

Geoeconomically, the (perceived) mishaps of the BRI in South Asia made Indian commentators further doubt the BRI's vision and its intentions. An example of the type of events that increased Indian doubts about BRI is the case of Sri Lanka's Hambantota Port, which a Chinese company ${ }^{18}$ obtained through a so-called debt-for-equity swap. Describing the kind of misgivings felt in India about the BRI, Khurana (2019: 28) writes that 'the BRI is seen 
as a Chinese project which capitalizes on other nation's vulnerabilities, desires and insecurities'. The same author describes the BRI as a Chinese attempt to move low-end sunset industries elsewhere (ibid.: 29). On the same subject, a Pakistani interviewee stated that India, backed by the US, had deliberately been marketing the BRI in the region as a debt trap solely serving China (interviewee based in Islamabad, September 2019, via Skype). There is also growing belief among Indian analysts that the initiative has limited economic rationale in South Asia, particularly as it relates to CPEC, and is rather aimed to constrain the rise of India (Katoch 2019:33). This sentiment is also reflective of the underpinnings of strategic distrust in Indian-Chinese ties. One Indian interlocutor even questioned the benefit the BRI could provide India (Delhi, September 2019). They remarked: 'We are not anti-China, but what do we actually gain if we sign onto the BRI? The initiative is not transparent at all, so what is the use?' It may help that Chinese foreign direct investment (FDI) in India has been growing consistently, so India is not necessarily losing out on the BRI (Basrur 2019).

Geostrategically, in this phase Indian policy and academic observers have cemented their view of the BRI as being primarily a unilateral Chinese project. One analyst, for example, stated that 'the more we thought about the economic rationale of Gwadar, Hambantota, and Chittagong Ports the less sense it made' (interview, Delhi, September 2019). As a result, India has slightly shifted away from its long-term non-alignment policy and taken a harder position on the strategic grid. Trust, or rather the deficit of it in the context of China's BRI, was also a key message of Prime Minister Modi's address on connectivity and cooperation at the 2018 Shangri-La Dialogue (Modi 2018). India sought closer security coordination with, e.g., the US, Japan, and Australia through the nascent 'quad', and by endorsing the Japan-US initiative to 'marry' the Indian Ocean space with the Pacific, the 'Indo-Pacific'.

Security concerns, logically, have also mounted. The Indian Navy spotted fourteen Chinese People's Liberation Army Navy warships in the Indian Ocean in 2017 (Singh 2019: 203). India's sovereignty and development depend - profoundly - on maritime security, and China's swift naval expansion through the Road is challenging this. To emphasize the gravity of the situation, an interviewee (Delhi, September 2019) said: 'We feel that we may succeed, or we may fail as a state in the coming 100 to 150 years. Much of this will depend on our naval power in the IOR. Delhi perceives the BRI not as a threat but as a major risk factor, as are the US and the EU, in this regard'. India's interest in the maritime domain is therefore not induced by the BRI, but it has highlighted a fundamental national security interest. 
Another analyst (interview, Delhi, September 2019), interestingly, and accurately, concluded that the BRI, thus far, has mostly been examined by India through a geopolitical and regional lens. India only looks at the BRI in South Asia and does not look too much beyond the region for its impact. Therefore, perceptions are biased and there is no full-picture analysis. Irrespective of this, as of the middle of 2020 India is still not at the BRI table. Indian agency, or its ability to influence or resist influence in South Asia, has simultaneously been limited and boosted by the BRI. India has set up a few small connectivity tables of its own and watches very closely what neighbours do, particularly Pakistan.

\section{Deep Seated - Afghanistan and Pakistan}

Of all the different connectivity visions that include Afghanistan, the BRI is by any measure the grandest and most ambitious. The Afghan government has consistently been very receptive to the BRI and signed a Memorandum of Understanding in 2016. The president, Ashraf Ghani, and his administration want to transform the landlocked and war-torn country into a logistical hub between Central and South Asia and welcome infrastructure investment. However, BRI progress in Afghanistan has been limited. In 2016, the Sino-Afghanistan Special Railway Transportation Project resulted in freight being delivered by train from Nantong, in China's eastern Jiangsu province, to Hairatan, in Afghanistan's northern Balkh province. In 2017, cargo moved two ways, but the exchange, by and large, can be considered symbolic. A fibre-optic cable was laid through the sliver of land that connects Afghanistan with China, the Wakhan Corridor (Jahanmal 2017), and a road is being built to connect the two countries through this rugged province (Foster 2019). However, Afghanistan simply is not a very attractive investment destination for the BRI as long as armed conflict and political instability linger. India is, nevertheless, working to connect with Afghanistan through Iran's Chabahar Port (Pakistan does not permit India to use its territory for transit). This is part of the International North-South Transport Corridor (INSTC) that aims to improve connectivity between India, Russia, Central Asia, Afghanistan, and Iran. ${ }^{19}$ In 2017, India even managed to ship wheat through Chabahar to Afghanistan.

Like Afghanistan, Pakistan is very much seated at the BRI table, though it has a much more prominent seat. As mentioned previously, Pakistan is

19 An agreement was signed by the initiative's founders, India, Russia, and Iran, in September 2000 . 
host to the China-Pakistan Economic Corridor (CPEC), which is the flagship corridor of the entire BRI. It is also the single largest recipient of BRI financial allocations, having received some US $\$ 60$ billion by April 2018 (Hillman 2018), an amount close to $7 \%$ of Pakistan's external loans (Hussain 2019: 4). Financing has taken place through investment projects, concessional loans, interest-free loans, and government grants (Chattha \& Hyder 2019: 106). China and Pakistan have had a very close relationship since $195^{\circ}$ when Pakistan was one of the first countries to cut diplomatic ties with the Republic of China on Taiwan. An aspiration to have a corridor between the two countries runs back to that same period and motivated construction of the Karakoram highway. Pakistan has always had a strategic need to have China on its side as a counterweight to Indian dominance and centrality in the region. However, China is not just a strategic balancer; it is also a 'replacement'. When the US grew increasingly disillusioned with Pakistan, following growing evidence of its support of the Taliban in Afghanistan, China was the most logical go-to actor for Pakistan's leaders. It is also not just the policy community that holds these views: China is seen as a more reliable and constructive strategic partner than the US according to popular sentiment (Pakistani interviewees based in Islamabad, September and October 2019, via Skype). Pakistan also desperately needs Chinese investment and is very welcoming of it, like Cambodia in Southeast Asia (see Ferchen on China and Southeast Asia, Chapter 10 in this volume). Chinese investment is anticipated to give a boost to the economy and help fight unemployment and terrorism. It is also seen as a solution to Pakistan's endemic energy crisis, which has long crippled the economy.

Nonetheless, the interdependence between China and Pakistan is not straightforward, and agency is rather complex and asymmetric. While financially China has the upper hand, Pakistan is at an advantage geographically and strategically (Afridi \& Khalid 2016: 669). Gwadar Port, located in Pakistan's southern Baluchistan Province, offers China virtually direct access to the Strait of Hormuz, through which some $40 \%$ of global daily oil transit fares. CPEC will also shorten the route for China's energy imports from the Middle East by about 12,00o kilometres (Bhattacharjee 2015: 2). Moreover, it gives China a strategically advantageous position in South Asia.

Although there has been near-unanimous support for the game-changing CPEC since the inception of the BRI, the corridor has been a topic of hot contestation in the Pakistani policy community. Once China and Pakistan started to plan, quarrels flared up within Pakistan over dividends, routes, and specific projects (interviewee based in Islamabad, September 2019, via 
Skype). This was particularly the case when the Nawaz Sharif administration shifted the initial short(er) route from Pakistan's west, running through Khyber-Pakhtunkhwa Province, to a route which would also run through Punjab Province in the east. This altered route significantly lengthened the distance down to Gwadar Port in Baluchistan Province. However, it connected the various urban centres in the country, including Lahore and Faisalabad, which are, respectively, Pakistan's second- and third-largest cities. The Sharif administration controlled tensions relatively well by holding broad consultations with political parties and social leaders, thereby mitigating a more negative perception and impact of CPEC (Hussain 2019: 10). At the Pakistani subnational level, sidelined stakeholders of CPEC, most notably the Balochis and the business community, have frequently expressed dissatisfaction about transparency and the distribution of spoils. Insurgents in both Khyber-Pakhtunkhwa and Baluchistan have blown up pipelines and on occasion even attacked Chinese engineers. The Pakistani military has stepped up in response and CPEC's construction has continued on pace.

CPEC is being built in phases that are under continuous review. It has just passed the 2015-2018 phase of so-called early harvest projects. Many of these projects focused on power plants (mostly fossil, but also renewable and nuclear) and on critical infrastructure. The second phase, which will focus on additional connectivity projects and gradual industrialization, coincides with a new administration. While he was in opposition, the incumbent Prime Minister Imran Khan strongly opposed CPEC modalities, but not the corridor itself. He said the initiative needed to be more transparent and fairer in regard to economic burden and debt sustainability, mostly pointing the finger at his predecessor (Hussain 2018). At that time, Khan did not hold political office so he could afford to take this position. However, when he came to power in 2018, he adopted a much softer stance towards CPEC, even on the renegotiations that he had previously demanded. Most of the project timelines had already been met by the time he took office. Nonetheless, the Khan administration is more careful when chalking out new projects. As a result, there is slightly more transparency now (Hussain 2019: 13-14). Some projects have been revised. For example, Pakistan has insisted that a larger airport be constructed in Gwadar. China has also learned from how the CPEC project has unfolded in Pakistan. For instance, because the Chinese state needs a secure investment climate it is now engaging frequently with Baloch leaders and giving more attention to local communities too (Abrar 2019). As a result the agency of these local actors has grown, after it had diminished in the initial years of the CPEC project. 


\section{Moved the Seat - Bangladesh, the Maldives, and Sri Lanka}

Bangladesh, the world's eighth most populous country, has fairly consistently and skilfully balanced policy between pursuing the benefits of the BRI and showing sensitivity to India's core concerns (Chakma 2019; Titumir \& Rahman 2019). India edges virtually the entire stretch of Bangladesh's borders. But, if anything, because of its investment needs Bangladesh has moved its seat closer to the BRI table since 2016. In the process, Bangladesh has achieved remarkable economic growth. It has enjoyed a GDP growth rate of no less than $7 \%$ since 2016 (World Bank Data 2020). ${ }^{20}$ To Bangladesh, the Road and the BCIM corridor appeal in particular as means to increase export-import capacity (Karim \& Islam 2018). Bangladesh is the only other country in South Asia, besides Pakistan, where the Belt and the Road components of the BRI connect. Not coincidentally, Bangladesh is the second-largest recipient of BRI loans in the region after Pakistan. By early 2018, China had implemented US\$10 billion worth of infrastructure projects (China Daily 2018). A notable example is cooperation on capacity development of Bangladesh's largest port, Chittagong. Nevertheless, Bangladesh is a very selective borrower and coordinates the BRI well with its own development priorities without bending to pressure from either China or India (Ramachandran 2019). Still, Bangladesh is more important to India than to China, for security, economic, political, geographic, and foreign-policy reasons (Chakma 2019: 228; Islam 2016). Demonstrative of this is the fact that India had been Bangladesh's top trading partner for 40 years until China took over in 2015 (Anwar 2019).

The Maldives is a clear-cut case of a state that has distanced its seat from the BRI table due to fear of overdependence on China and a political leadership swing. The nearly 1200 islands that comprise the Maldives sit right in the middle of the Indian Ocean. This is a highly strategic setting among key international shipping lanes and has long been under India's political influence. Chinese diplomatic overtures, such as Chinese President Xi Jinping's visit to the archipelago in 2014, and BRI-related financial injections, helped to turn the tide during the five years that President Abdullah Yameen was in office, with his administration engaging in extensive borrowing. The Maldives even signed a Free Trade Agreement with China in 2017. Based on 2017 figures, the Maldives's debt to China accounted for $27 \%$ of external debt, though only $8.6 \%$ of total debt (Samaranayake 2019: 12). Yameen's successor, 
Ibrahim Mohamed Solih, who ousted him in a landslide victory in the 2018 elections, rectified the marginalization of India and overdependence on China under Yameen. After all, India is the central actor in the Maldives's greater geography. President Solih also tried to rescind BRI projects that were perceived as having inflated prices, but many had already been completed (Elmer 2019).

Like the Maldives, Sri Lanka is also strategically located along the EuropeAsia trade route as a low-cost transit point. It also lends itself well for foreign offshore supply to security and naval activities in the Indian Ocean. Shifts in the political landscape and growing debt concerns, even though China only holds an estimated $12 \%$ of Sri Lanka's external debt (Samaranayake 2019: 6), ${ }^{21}$ have also altered policy stances on the BRI. However, more than the Maldives, Sri Lanka is entangled in a power play that, besides China and India, also includes Japan and the US (the country's top export destination). Both China and India have attempted to influence Sri Lankan domestic politics. In turn, Sri Lanka has tried to play them against each other. Initially there was a pro-China tilt that translated into numerous BRI projects. In 2017, China accounted for $35 \%$ of foreign direct investment, more than twice India's 16\% share (Xavier 2020). The 99-year Hambantota Port lease sent shockwaves through global media, but the debt-for-equity swap was incompletely portrayed in Indian and Western media (Elmer 2019; Sautman and Yan 2019). Since 2019, the new Sri Lankan government led by President Gotabaya Rajapaksa has pursued agency that seeks to better balance foreign influence and maximize benefits to Sri Lanka. Chinese-Indian strategic distrust is a useful reality in that regard. President Rajapaksa has clearly warned, though, that unless powers other than China invest in the country, the BRI will prevail (Elmer 2019).

\section{To Sit or Not to Sit - Nepal}

While Sri Lanka's geographic setting means it can draw from a diverse pool of international interest, Nepal's setting is much less exploitable. Rugged Nepal is exemplary of a politically divided country that is (over)dependent for transit and investment on both India and China and accordingly needs to balance between the two. Nepal was an early BRI signatory in 2014, the same year that Chinese investment in the country surpassed that of India. Not long after this, Nepali authorities accused India of blockading the transit of (mostly) fuel and vital goods to Nepal (BBC 2015). As a result, Nepal has 
veered a little closer to China, but the country does not have a very coherent foreign policy due to political fragmentation. India wants to maintain Nepal within its sphere of influence, while China is actively working to pull it away. The Modi administration worries that the Belt will grant China (further) direct access to its territory (Sapkota 2017). It is important to realize that Nepal is landlocked and is enclosed by India on three sides and China on the other. As a result, India has had a de facto monopoly on Nepali exports. The BRI could change this. Nonetheless, perceptions of the BRI amongst academics and politicians range from lukewarm to positive (Sapkota 2017: 115). In the policy community this old division mostly runs along the fault lines between the single largest party, the pro-India Nepal Congress, and the pro-China Nepal Communist Party that currently rules. There are a number of reasons that specifically drive Nepali interest in the BRI. The most significant is that it could increase international trade and transform Nepal from a landlocked to a land-linked country (Shrestha 2017: 36; Panda 2019). Much of this revolves around the Trans-Himalayan Economic Corridor, part of the BRI. ${ }^{22}$ Nepal is a demonstrative of the weight and complex interplay of South Asia's three critical realities. It also indicates how this complex interplay can, potentially, be turned to an agency advantage by a small regional actor.

\section{Conclusion}

BRI impact on connectivity and integration in South Asia is dissimilar to any other region where the initiative is active. Three interrelated elements help produce this dissimilarity. The first is the region's distinct geographic reality. Emerging India is literally and allegorically the centre. Meanwhile, the more-swiftly re-emerging China is an immediate neighbour to all but one continental South Asian state. The second element is the way the region has a congregation of various, deep-rooted geopolitical fissures, most notably deep antagonism between its two largest actors, India and Pakistan. The third element is the severe strategic distrust of China in the Indian policy and military community, as well as in much of the Indian academic community. BRI connectivity in South Asia has consequently had to work its

22 This corridor could act as a land bridge between China and India and improve transit with and reduce transit costs to the Tibet Autonomous Region, Sichuan, and Yunnan (Adhikari 2018: 47-49). Together with CPEC, BCIM, and the Road, it is one of four main BRI subprojects in South Asia. 
way around India. Therefore, despite select improvements of national and select extra-national connectivity in Pakistan and smaller states, the BRI has not been able to genuinely integrate the region more closely - at least so far. However, the initiative has triggered a host of connectivity initiatives in South Asia, led mostly by India as well as by extra-regional powers. As a result of this and greater diversity of investors, the agency of South Asian states other than India has, on balance, improved - as has China's. Scholars should take note of this. The BRI has also given a highly fragmented region stronger impetus to connect, which is a remarkable accomplishment. Nonetheless, the BRI has intensified historical tensions between China-Pakistan versus India. It has also helped sustain the India-Pakistan rift. Moreover, the BRI has led to a further internationalization and complication of the region's geopolitics - including the geopolitics of the Indian Ocean.

The evolution of perceptions of the BRI, as well as policy responses to it, in South Asia differs from the evolution seen in other parts of the world. The changing perceptions of BRI and policy responses in the region can be characterized by drawing an analogy with who is seated at the figurative BRI table. India has been very consistent: it never took a seat. Since the BRI's inception, India has been suspicious of the economic rationale, and lack of transparency and multilateralism of the initiative. Of India's traditional foreign policy attributes of independence of action alongside a level of realism and idealism, the BRI has mostly hit the realism string. This string has continued to vibrate as the BRI has unfolded rapidly in India's sphere of influence. India has been actively seeking to compensate for the deliberate disconnection policies that it pursued for most of the second half of the twentieth century. That said, India does not have the diplomatic, financial, and administrative clout of the BRI. Therefore, Indian agency has simultaneously been limited and boosted by the BRI. War-torn Afghanistan, and Pakistan, both thirsty for investment, have also been very consistent in their BRI policies. However, contrary to India they both have very much taken a seat at the BRI table. In Pakistan, the policy community under the incumbent Prime Minister Imran Khan has become more involved and slightly more cautious in CPEC planning. The Maldives, Nepal, Sri Lanka, and Bangladesh have all become frontlines for Indian-Chinese competition over influence and investment. Sri Lanka and the Maldives have readjusted their interest in BRI following political leadership swings, concerns over the sustainability of external debt, and wariness over long-term strategic costs. They have distanced their seats a little from the BRI table. On the contrary, the selective-borrower Bangladesh has continuously been able to smartly 
negotiate BRI investments while tending to Indian core interests. Politically divided Nepal, landlocked between China and India, has taken a seat to lessen a long-term overdependence on India.

These responses indicate that countering the BRI by a regional power, in this case, India, is of limited effect in a geopolitically fragmented region that yearns for investment, improved connectivity, and a power balance. Despite having grown slightly less enthusiastic and cautious, South Asia, bar India, still welcomes BRI investments. Nevertheless, if India and China do not sit at the same regional connectivity table, the initiative will not truly integrate the region, and will sustain regional divisions.

\section{References}

Abrar, Mian (2019, September 11). 'Baloch Leaders Extend Support to CPEC during China Visit'. Pakistan Today. Retrieved 13 March 2020 from https://www.pakistantoday. com.pk/2019/og/11/baloch-leaders-extend-support-to-cpec-during-china-visit/.

Adhikari, Ashish (2018). 'Belt and Road Initiative and Nepal's Economic Perspective: Regionality and Specificity'. Kathmandu School of Law Review, 6(1), 41-52.

Afridi, Manzoor Khan \& Khalid, Imram (2016). 'The Politics of Interdependence: A Case of China-Pakistan Economic Corridor'. South Asian Studies, 31(2), 659-671. Anwar, Anu (2019, July 15). 'How Bangladesh Is Benefiting from the China-India Rivalry'. South Asia Journal. Retrieved 22 March 2020 from http://southasiajournal.net/how-bangladesh-is-benefiting-from-the-china-india-rivalry/.

Barfield, Thomas (2010). Afghanistan: A Cultural and Political History. Princeton: Princeton University Press.

Basrur, Ajesh (2019). 'The BRI and India's Grand Strategy'. Strategic Analysis, 43(3), 187-192.

BBC (2015, December 15). 'Nepal Blockade: Six Ways It Affects the Country'. BBC. Retrieved 3 March 2020 from https://www.bbc.com/news/world-asia-35041366. Bhattacharjee, Dhrubajyoti (2015, May 12). 'China Pakistan Economic Corridor (CPEC)'. Issue Brief. Indian Council of World Affairs. Retrieved 20 March 2020 from https://papers.ssrn.com/sol3/papers.cfm?abstract_id=2608927.

Bhattarai, Kamal Dev (2017, January 6). 'India and China's Tug of War over Nepal'. The Diplomat. Retrieved 4 March 2020 from https://thediplomat.com/2017/01/ india-and-chinas-tug-of-war-over-nepal/.

Borah, Rupakjyoti (2018). 'The Maritime Silk Road in China's OBOR (One Belt One Road) Initiative: How Should India Respond?' Asian Studies, 64(3), 10-17.

Brewster, David (2016). 'Silk Roads and Strings of Pearls: The Strategic Geography of China's New Pathways in the Indian Ocean'. Geopolitics, 22(2). 271-72. 
Chakma, Bhumitra (2019). 'The BRI and Sino-Indian Geo-economic Competition in Bangladesh: Coping Strategy of a Small State'. Strategic Analysis, 43(3), 227-239. Chattha, Muhammad Khudadad \& Hyder, Mustafa (2019). 'China-Pakistan Economic Corridor: Where Is the Money Going?' Journal of Infrastructure, Policy and Development, 3(1), 100-114.

Chhibber, Ajay (2017). 'China's Belt and Road Initiative and India's Options: Competitive Cooperation'. Journal of Infrastructure, Policy and Development, 1(2), 1-12.

China Daily (2018, March 22). 'China Implements \$1ob Worth of Infrastructure Projects in Bangladesh, Says Ambassador'. China Daily. Retrieved 19 March 2020 from http://www.chinadaily.com.cn/a/201803/22/WS5ab36aoaa3105cdcf65139df. html.

Elmer, Keegan (2019, December 1). 'Sri Lankan President Gotabhaya Rajapaksa Plays Down Links with China on Trip to India'. South China Morning Post. Retrieved 21 March 2020 from https://www.scmp.com/news/china/diplomacy/ article/3040119/sri-lankan-president-gotabhaya-rajapaksa-plays-downs-links.

Fengler, Wolfgang \& Vallely, Paul (2019, September 9). 'Connecting Central Asia to the World'. Brookings, Future Development Blog. Retrieved 16 February 2020 from https://www.brookings.edu/blog/future-development/2019/og/og/ connecting-central-asia-to-the-world/.

Foster, Kendrick (2019, December 5). 'The New Road to Conflict: Geopolitics of the Wakhan Corridor'. Harvard International Review. Retrieved 14 March 2020 from https://hir.harvard.edu/wakhancorridor/.

Ganapathy, Nirmala (2018, December 17). 'India Offers \$1.9 Billion Financial Aid to Maldives to Counter China's Influence'. Straits Times. Retrieved 19 April 2020 from https://www.straitstimes.com/asia/south-asia/india-offers-19-billionfinancial-aid-to-maldives-to-counter-chinas-influence.

Ghiasy, Richard (2018). China's Belt and Road Initiative: Security Implications and Ways Forward for the European Union. Policy Brief. Stockholm International Peace Research Institute (SIPRI). Retrieved 26 January 2020 from https://sipri.org/ publications/2018/other-publications/chinas-belt-and-road-initiative-securityimplications-and-ways-forward-european-union.

Ghiasy, Richard, Su, Fei \& Saalman, Lora (2018). The 21st Century Maritime Silk Road: Security Implications and Ways Forward for the European Union. Stockholm International Peace Research Institute (SIPRI). Retrieved 26 January 2020 from https://www.sipri.org/publications/2018/other-publications/21st-centurymaritime-silk-road-security-implications-and-ways-forward-european-union.

Grant, Charles (2010). India's Response to China's Rise. Policy Brief. Center for European Reform. Retrieved 6 February 2020 from https://www.cer.eu/sites/default/ files/publications/attachments/pdf/2011/pb_india_china_grant_aug10-206.pdf. Guha, Ramachandra (2017). India after Gandhi. London: MacMillan. 
Hillman, Jonathan E. (2018, April 3). 'How Big Is China's Belt and Road?' Center for Strategic \& International Studies (CSIS). Retrieved 21 February 2020 from https://www.csis.org/analysis/how-big-chinas-belt-and-road.

Hussain, Ejaz (2019). 'Will Change in Government Affect China-Pakistan Economic Corridor? The BRI, CPEC and the Khan Government: An Analysis'. Chinese Journal of International Review, 1(2).

Hussain, Tom (2018, August 12). 'Where Does Imran Khan's Government Stand on China's Belt and Road?' South China Morning Post. Retrieved 4 March 2020 from https://www.scmp.com/week-asia/geopolitics/article/2159245/ where-does-imran-khans-government-stand-chinas-belt-and-road.

Islam, Muinul (2016). Regional Connectivity: Current Challenges for Bangladesh. Paper prepared for presentation in the regional seminar of the Bangladesh Economic Association-Chittagong Chapter. Retrieved 20 March 2020 from https://www.bea-bd.org/site/images/pdf/mui.pdf.

Jahanmal, Zabihullah (2017, April 22). 'Afghanistan, China to Connect through Fiber Optic Network'. Tolo News. Retrieved 10 March 2020 from https://tolonews.com/ business/afghanistan-china-connect-through-fiber-optic-network.

Kaplan, Robert D. (2013). The Revenge of Geography. New York: Random House.

Karim, Mohd Aminul \& Islam, Faria (2018). 'Bangladesh-China-India-Myanmar (BCIM) Economic Corridor: Challenges and Prospects'. Korean Journal ofDefense Analysis, 30(2), 283-302.

Katoch, Dhruv (ed.) (2019). India's Foreign Policy: Towards Resurgence. New Delhi: Pentagon Press.

Khurana, Gurpreet S. (2019). 'India as a Challenge to China's Belt and Road Initiative'. Asia Policy, 14(2), 27-33.

Marshall, Tim (2019). Prisoners of Geography. London: Elliott and Thompson.

Ministry of External Affairs (2017, May 13). 'Official Spokesperson's Response to a Query on Participation of India in OBOR/BRI Forum'. Government of India. Retrieved 6 July 2020 from https://mea.gov.in/media-briefings.htm?dtl/28463/Official+Spoke spersons+response+to+a+query+on+participation+of+India+in+OBORBRI+Forum.

Modi, Narendra (2018). 'Prime Minister's Keynote Address at Shangri La Dialogue (June 01, 2018)'. Ministry of External Affairs, Government of India. Retrieved 10 December 2019 from https:/www.mea.gov.in/Speeches-Statements.htm?dtl/29943/ Prime+Ministers+Keynote+Address+at+Shangri+La+Dialogue+June+01+2018.

Mohan, C. Raja (2014a, August 13). 'Chinese Takeaway: One Belt One Road'. Indian Express. Retrieved 23 February 2020 from https://indianexpress.com/article/ opinion/columns/chinese-takeaway-one-belt-one-road/.

Mohan, C. Raja (2014b, September 15). 'Silk Route to Beijing'. Indian Express. Retrieved 23 February 2020 from https://indianexpress.com/article/opinion/ columns/silk-route-to-beijing/. 
Murton, Galen, Lord, Austin \& Beazley, Robert (2016). 'A Handshake across the Himalayas: Chinese Investment, Hydropower Development, and State Formation in Nepal'. Eurasian Geography and Economics, 57(3), 403-432.

Nataraj, Geethanjali \& Sekhani, Richa (2015). China's One Belt One Road - An Indian Perspective. Economic and Political Weekly, L(49), 67-71.

Onmanorama (2020, June 17). 'Despite Modi's 5 China Trips \& 18 Meetings with Xi, Sino-Indian Border Dispute Escalates'. Retrieved 6 July 2020 from https:// www.onmanorama.com/news/nation/2020/06/17/narendra-modi-china-sinoindia-border-dispute.html.

Panda, Jagannath P. (2019, November 4). 'Xi's Nepal Visit Reveals a Grander Chinese Himalayan Approach'. Institute for Defence Studies and Analyses. Comment. Retrieved 17 March 2020 from https://idsa.in/idsacomments/ xi-nepal-visit-jpanda-mrittika-041119.

Pande, Aparna (2018). From Chanakya to Modi: Evolution of India's Foreign Policy. Noida: HarperCollins.

Ramachandran, Sudha (2019, July 22). 'How Bangladesh Learned to Love the Belt and Road'. The Diplomat. Retrieved 13 March 2020 from https://thediplomat. com/2019/o7/how-bangladesh-learned-to-love-the-belt-and-road/.

Sachdeva, Gulshan (2018). 'Indian Perceptions of the Chinese Belt and Road Initiative'. International Studies, 55(4), 285-296.

Samaranayake, Nilanthi (2019, April). 'China's Engagement with Smaller South Asian Countries'. Special Report no. 446. United States Institute of Peace (USIP). Retrieved 4 March 2020 from https://www.usip.org/publications/2019/o4/ chinas-engagement-smaller-south-asian-countries.

Sapkota, Rupak (2017). 'Nepal in the Belt and Road: New Vista on Building a ChinaIndia-Nepal Economic Corridor'. China International Studies, Nov.-Dec., 105-121.

Sautman, Barry \& Hairong, Yan (2019, May 6). 'The Truth about Sri Lanka's Hambantota Port, Chinese "Debt Traps" and "Asset Seizures"'. South China Morning Post. Retrieved 12 March 2020 from https://www.scmp.com/comment/ insight-opinion/article/3008799/truth-about-sri-lankas-hambantota-portchinese-debt-traps.

Shrestha, Min B. (2017). 'Cooperation on Finance Between China and Nepal: Belt and Road Initiatives and Investment Opportunities in Nepal'.Journal of Finance and Data Science, 3, 31-37.

Sibal, Kanwal (2014, February 25). 'Silk Route to Tie India in Knots'. Ministry of External Affairs, Government of India. Retrieved 10 December 2019 from https://mea.gov.in/articles-in-indian-media.htm?dtl/22999/Silk+route+to+tie +India+in+knots.

Singh, Abhijit (2019). 'Sino-Indian Dynamics in Littoral Asia: The View from New Delhi'. Strategic Analysis, 43(3), 199-121. 
Singh, Zorawar Daulet (2014). 'Indian Perceptions of China's Maritime Silk Road Idea.' Journal of Defence Studies, 8(4), 133-148.

Song, Lei Lei (2019, August 2). 'How South Asia Can Continue as World's Fastest Growing Subregion'. Asian Development Bank. Retrieved 19 February 2020 from https://www.adb.org/news/op-ed/how-south-asia-can-continueworld-s-fastest-growing-subregion-lei-lei-song.

Times of India (2020, February 23). 'US Surpasses China to Become India's Top Trading Partner'. Times of India. Retrieved 23 February 2020 from http://timesofindia. indiatimes.com/articleshow/74264798.cms?utm_source=contentofinterest\& utm_medium=text\&utm_campaign=cppst.

Titumir, Rashed Al Mahmud \& Rahman, Zahidur (2019). 'Strategic Implications of China's Belt and Road Initiative (BRI): The Case of Bangladesh'. China and the World 2(3), 1-59.

Uberoi, Patricia (2016). 'Problems and Prospects of the BCIM Economic Corridor'. China Report, 52(1), 19-44.

World Bank (2018). 'Realizing the Promise of Regional Trade in South Asia'. Retrieved ${ }_{17}$ February 2020 from https://www.worldbank.org/en/news/feature/2018/10/og/ realizing-the-promise-of-regional-trade-in-south-asia.

World Bank Data (2020). Retrieved 17 February 2020 from https://data.worldbank. org/region/south-asia.

Xavier, Constantino (2020, January). 'Sambandh as Strategy: India's New Approach to Regional Connectivity'. Brookings India Policy Brief 012020-01. Brookings Institution India Center. Retrieved 31 January 2020 from https://www.brookings.edu/wp-content/uploads/2020/o1/India's-New-Approach-to-RegionalConnectivity-V/_M.pdf.

\section{About the Author}

RiCHARD GHIASY is a Senior Fellow at LeidenAsiaCentre and a Subject Matter Expert at The Hague Centre for Strategic Studies (HCSS). His main interests lie in Asian geopolitics and geoeconomics, EU-Asia relations, China's foreign and security policy, and conflict prevention. As a former Associate Researcher at Stockholm International Peace Research Institute (SIPRI), he has provided policy advice to inter alia the EEAS, European Commission, government ministries, the Organization for Security and Co-operation in Europe (OSCE), and the Organisation for Economic Cooperation and Development (OECD). Richard is a member of the Belt and Road Research Platform and the Stockholm Observatory for Global China at the Swedish Institute of International Affairs (UI). 